\title{
Peningkatan Prestasi Belajar Mahasiswa Pendidikan Teknik Otomotif Pada Pembelajaran Praktik Teknik Pembentukan Dasar dengan Menggunakan Metode Project Based Learning
}

\author{
Eksel Chandra Kartika Putra, Suyitno \\ Program Studi Pendidikan Teknik Otomotif. FKIP. Universitas Muhammadiyah Purworejo. \\ ekselr2b@gmail.com, yitno@umpwr.ac.id
}

\section{ABSTRAK}

Penelitian ini merupakan Penilitian Tindakan Kelas (PTK) dan setiap siklus dimulai dari perencanaan (planning), tindakan (Action), pengamatan (observation) dan refleksi (reflection). Subyek penelitian adalah mahasiswa semester II Program Studi Pendidikan Teknik Otomotif UM Purworejo dengan jumlah total 36 mahasiswa. Pengumpulan data menggunakan teknik observasi, catatan lapangan, wawancara dan studi dokumen. Analisis data dalam penelitian ini dilakukan sebelum dilakukan perlakukan, pada saat pelakuan dan setelah dilakukan perlakuan. Pada pra-siklus dilakukan terhadap data hasil study pendahuluan yang akan digunakan untuk menentukan fokus penelitian. Dari data hasil penelitian selama proses pembelajaran diolah dan dianalisis secara deskripsi kualitatif.

Berdasarkan data yang diperoleh dalam pembahasan hasil penelitian penerapan model Project Based Learning pada pembelajaran praktik Teknik Pembentukan Dasar dalam meningkatkan prestasi belajar mahasiswa semester II Progam Studi Pendidikan Teknik Otomotif tahun ajaran 2019/2020 dapat disimpulkan sebagai berikut; a). Penilaian prestasi mahasiswa dilihat dari tingkat hasil kerja siswa sebelum tindakan pada nilai rata-rata 65,8 dengan prosentase tingkat kelulusan sebesar $=13,89 \%$, b). Di siklus I pada nilai rata-rata 73,8 dengan prosentase tingkat kelulusan sebesar $=72,22 \%$ dan c). Pada siklus II nilai rata-rata 82,0 dengan prosentase tingkat kelulusan sebesar $=100 \%$. Setelah menganalisis hasil tindakan setiap siklus dapat diketahui bahwa hasil data setiap siklus mengalami peningkatan, terutama pada siklus II, yang menjelaskan peningkatan yang signifikan pada prosentase sebesar $100 \%$ dari seluruh siswa dengan jumlah 36 mahasiswa, sehingga penerapan model pembelajaran ini dalam katagori berhasil

Kata Kunci: Prestasi Belajar, Teknik Pembentukan, Project Based Learning 


\section{A. PENDAHULUAN}

Pendidikan Kejuruan merupakan bagian salah satu penentu pengembangan kemajuan ilmu pengetahuan dan teknologi dan tingkatan pendidikan yang menekankan pada bidang keahlian tertentu yang harus dimiliki oleh siswa. Hal tersebut yang mendasari setelah lulus, siswa dituntut untuk memiliki keahlian dan menguasai tertentu sehingga sikap aktif, kreatif, dan inovatif akan terwujud. Dasar belajar adalah asosiasi antara kesan (impression) dengan dorongan untuk berbuat (impuls to action). Asosisasi itu menjadi kuat atau lemah dengan terbentuknya atau hilangnya kebiasaankebiasaan. Perubahan tersebut diperoleh melalui usaha (bukan karena kematangan), menetap dalam waktu yang relatif lama dan merupakan hasil pengalaman menurut Bower dan Hilgard (Purwanto 2013:39) belajar adalah aktivitas mental atau psikologi yang berlangsung dalam interaksi aktif dengan lingkungan yang menghasilkan perubahan-perubahan dalam pengetahuan, keterampilan dan sikap. diharapkan mahasiswa mampu mengembangkan materi pembelajaran yang telah diberikan. Proses pembelajaran di dunia kerja dimaksud supaya siswa menguasai kompetensi keahlian, mengembangkan sikap dan nilai professional sebagai sehingga mengasilkan lulusan yang berkualitas. Pendidik (dosen) sering menghadapi masalah dalam proses pembelajaran misal mahasiswa yang tidak dapat mengikuti pembelajaran dengan lancar, ada mahasiswa yang sulit mengerti akan pembelajarannya, akibatnya beberapa mahasiswa mendapatkan prestasi belajar dan pemahaman yang rendah.

Dalam menghadapi mahasiswa yang mengalami kesulitan belajar, penting bagi dosen untuk merefleksi cara mengajarnya dan apakah metode atau pendekatan dengan perpaduan model pembelajaran yang diterapkan dalam proses pembelajaran sesuai dengan materi yang akan diajarkan dan dapat diterima oleh seluruh mahasiswa. Proses pembelajaran sebisa mungkin harus melibatkan para mahasiswa dalam memecahkan suatu permasalahan dan memberikan kesempatan kepada para 
mahasiswa untuk ikut serta berperan aktif dalam pembelajarannya sehingga hasil belajar maksimal.

Menurut Gagne \& Briggs (Suprihatiningrum 2016:37) hasil belajar adalah kemampuan-kemampuan yang dimiliki peserta didik sebagai akibat perbuatan belajar dan dapat diamati melalui penampilan peserta didik. Hasil belajar sangat berkaitan dengan belajar dan proses pembelajaran. Hasil belajar akan maksimal ketika belajar dan proses pembelajaran berjalan dengan baik. Peserta didik dapat dikatakan sudah mencapai hasil belajar ketika peserta didik tersebut telah terjadi perubahan perilaku melalui proses pembelajaran. Perubahan perilaku diperoleh peserta didik ketika sudah menyelesaikan program pembelajarannya melalui interaksi dengan berbagai sumber belajar dan lingkungan belajar.

Berdasarkan hasil observasi melalui wawancara dengan dosen pengampu dan juga pengamatan langsung pada saat pembelajaran kompetensi teknik pengelasan mata kuliah Teknologi Pembentukan Dasar pada semester II Program Pendidikan Teknik Otomotif UM Purworejo ditemukan bahwa; 1) pembelajaran yang diterapkan kurang efektif jika melihat alokasi waktu yang harusnya membutuhkan waktu yang lebih efektif dalam belajar khususnya kompetensi; 2) penggunaan model demonstrasi yang verbalistik dan cenderung monoton mengakibatkan mahasiswa merasa bosan dan kurang tertarik mengikuti pembelajaran; 3) model lain yang digunakan dosen adalah penugasan dan latihan secara individu dinilai kurang melatih siswa untuk berkolaborasi dan bersosialisasi dengan dosen maupun sesama mahasiswa; 4) model pembelajaran yang masih menitikberatkan pada teori dan hasil dari tugas praktik tanpa mementingkan proses dari pelaksanaan praktik; 5) saat kegiatan praktik berlangsung sebagian siswa terpaku pada hasil akhir dari tugas yang diberikan tanpa melihat urutan kegiatan praktik dan keselamatan kerja. 6) Penilaian dengan menggunakan hasil akhir tidak menjamin mahasiswa dapat bekerja dengan benar dan mempunyai hasil belajar yang diharapkan sehingga hasil belajar mahasiswa belum maksimal; 7) media pembelajaran praktikum yang masih kurang mendukung, sehingga mahasiswa masih 
mengalami kesulitan dalam hal kemampuan untuk menginovasi dan kreativitas untuk mengembangkan pengetahuan teori yang telah diperoleh untuk mengaplikasikannya.

Dari kajian awal permasalahn dilapangan tersebut pada dasarnya, diperlukan pendekatan pembelajaran yang efektif untuk mengaktifkan peran mahasiswa, sehingga memiliki pengembangan keilmuan yang didapatkan baik dan yang nantinya berimbas terhadap hasil pembelajaran yang baik pula. Salah satu alternatif yang perlu diterapkan adalah model pembelajaran Student Centered yaitu Project Based Learning (PjBL) atau pembelajaran berbasis proyek. Pembelajaran Berbasis Proyek adalah model pembelajaran sistematik yang mengikutsertakan peserta didiknya kedalam pembelajaran teoritis dan keahlian yang kompleks, pertanyaan otentik dan perancangan produk dan tugas.

Model Project Based Learning (PBL) merupakan suatu model pembelajaran yang melibatkan suatu pembelajaran berbasis proyek (Project Based Learning) merupakan model pembelajaran yang menggunakan proyek atau kegiatan sebagai media. Model pembelajaran berbasis proyek merupakan pemberian tugas kepada semua peserta didik untuk dikerjakan secara individual, peserta didik dituntut untuk mengamati, membaca dan meneliti (Purwadinata, 2013).

\section{B. METODE PENELITIAN}

Penelitian ini termasuk jenis penelitian tindakan kelas (classroom action research) yang dilakukan secara kolaboratif dan partisipatif, artinya peneliti tidak melakukan penelitian sendiri, namun berkolaborasi atau bekerja sama dengan dosen pengampu pembelajaran praktik. Penelitian ini dilakukan di Program Studi Pendidikan Teknik Otomotif FKIP UM Purworejo. Subyek penelitian adalah mahasiswa kelas B Program Studi Pendidikan Teknik Otomotif tahun pelajaran 2019/2020 semester II dengan jumlah mahasiswa 36 Penentuan subyek ini diambil karena kelas B merupakan kelas yang mempunyai prestasi kurang diantara kelas yang lainnya pada Kompetensi Pembelajaran Praktik Teknik Pembentukan Dasar. Proses pengumpulan data merupakan langkah penting dari prosedur penelitian, Autotech: Jurnal Pendidikan Teknik Otomotif Universitas Muhammadiyah Purworejo 
data analisis untuk membuat deskripsi dan inferensi penelitian, dengan demikian yang diperoleh merupakan data yang valid dan reliabel. Untuk memperoleh data dalam penelitian ini digunakan beberapa teknik pengumpulan data observasi, tes unjuk kerja dan dokumentasi. Analisis yang digunakan terdapat dua macam pendekatan deskriptif, yaitu deskriptif kualitatif dan deskriptif kuantitatif. Analisis kualitatif adalah analisis pada proses pengamatan meliputi catatan lapangan saat menggunakan metode PBL. Analisis kuantitatif memberikan gambaran tentang kemajuan pembelajaran dikelas, dan untuk melihat perkembangan prestasi.

Penelitian ini menggunakan pendekatan kuantitatif untuk menganalisis data berupa hasil tes, Karena datanya berupa persentase hasil belajar mahasiswa dan nilai rata-rata, data disajikan dalam bentuk table dan diagram, sedangkan pendekatan kualitatif digunakan untuk menganalis data berupa hasil observasi selama proses pembelajaran berlangsung

\section{HASIL PENELITIAN DAN PEMBAHASAN}

Penelitian tindakan kelas praktik mengelas menggunakan model pembelajaran Project Based Learning di Program Studi Pendidikan Teknik Otomotif berlangsung dalam dua siklus. Siklus I sampai dengan siklus II menggunakan tindakan berbedabeda, disiklus terakhir mendapat kriteria keberhasilan sesuai dengan yang dinyatakan berhasil jika 80\% sudah mencapai atau melampaui gread nilai B (80-89). Pembahasan terhadap permasalahan penelitian berdasarkan analisis data hasil penelitian dari kinerja kolaborasi antara peneliti, koloborator dan tanggapan dosen pengampu yang terlibat dalam kegiatan ini, yang dimulai dari dialog awal, perencanaan tindakan dan pelaksanaan tindakan.

Prestasi pembelajaran pada penelitian tindakan ini didasarkan atas proses pembelajaran, dan hasil kerja. Prestasi pembelajaran dikatakan baik apabila mendapatkan kriteria pada indikator menjadi sangat baik atau sesuai dengan 
indikator yang telah ditentukan. Berikut ini adalah penilaian dari kualitas pembelajaran yang telah dilakukan dalam penelitian tindakan:

Hasil kerja siswa dalam proses pembelajaran terdiri dari beberapa indikator penilaian yaitu persiapan kerja, proses, hasil kerja, sikap kerja, dan waktu yang dibutuhkan. Berikut ini adalah hasil nilai siswa dalam proses pembelajaran mengelas menggunakan model PBL yang telah dilaksanakan:

Tabel 1

\begin{tabular}{|c|c|c|}
\hline Penillaian & Rata - rata & Tingkat Kelulusan \\
\hline Sebelum Tindakan & 65,8 & $13,89 \%$ \\
\hline Siklus 1 & 73,8 & $72,22 \%$ \\
\hline Siklus 2 & 82,0 & $100 \%$ \\
\hline
\end{tabular}

Tingkat Hasil Nilai Mahasiswa dengan Model Project Based Learning

Berdasarkan tabel di atas terlihat bahwa sebelum tindakan dilakukan nilai pratikum sebesar 65,8 dengan tingkat kelulusan sebesar $13,89 \%$, setelah melakukan tindakan pada siklus I maka nilai siswa yang didapat mahasiswa meningkat menjadi 73,8 dengan tingkat kelulusan $72,22 \%$, selanjutnya pada siklus II mengalami peningkatan nilai rata-rata menjadi 82,0 dengan tingkat kelulusan sebesar $100 \%$. Nilai hasil kerja mahasiswa setelah menggunakan metode pembelajaran $P B L$ selalu mengalami kenaikan, sehingga tingkat nilai siswa yang mempunyai nilai di atas nilai kriteria ketuntasan sebesar $100 \%$ atau mempunyai kategori sangat baik. Hasil tersebut dapat disimpulkan bahwa metode pembelajaran Project Based Learning dapat meningkatkan nilai belajar siswa dalam pembelajaran teknik pengelasan, hal tersebut berdampak juga terhadap peningkatan prestasi pembelajaran teknik pengelasan. Pada kategori $\mathrm{n}$ ila i hasil kerja mahasiswa dikatakan berhasil apabila sudah mendapatkan nilai minimal kriteria ketuntasan sebesar 76 , dilihat dari tabel di atas bahwa pada siklus I sudah di atas KKM, akan tetapi jika dilihat secara detail dari sub kompetensi, maka terdapat nilai yang masih dibawah nilai kriteria Autotech: Jurnal Pendidikan Teknik Otomotif Universitas Muhammadiyah Purworejo 
ketuntasan, sehingga perlu adanya tindak lanjut, yaitu pada siklus 2. Pada siklus II tindakan diakhiri pada siklus kedua, karena pada siklus II sudah masuk dalam indikator keberhasilan yang sudah ditentukan.

\section{SIMPULAN DAN SARAN}

Berdasarkan data yang diperoleh dalam pembahasan hasil penelitian penerapan model Project Based Learning pada pembelajaran praktik Teknik Pembentukan Dasar dalam meningkatkan prestasi belajar mahasiswa semester II Progam Studi Pendidikan Teknik Otomotif tahun ajaran 2019/2020 dapat disimpulkan sebagai berikut; 1) Tahapan pembelajaran praktik teknik pembentukan dasar pada mahasiswa Semester II Pendidikan Teknik Otomotif dengan Menggunakan Metode Project Based Learning terdiri dari 6 langkah pembelajaran yaitu dimulai dengan pertanyaan yang esensial, perencanaan aturan pengerjaan proyek, membuat jadwal aktivitas, memonitoring perkembangan proyek peseta didik, penilaian hasil kerja mahasiswa, evaluasi pengalaman belajar mahasiswa; dan 2) Peningkatan prestasi belajar praktik teknik pembentukan dasar mahasiswa Semester II Pendidikan Teknik Otomotif dengan Menggunakan Metode Project Based Learning dapat dilihat dari hasil kerja mahasiswa sebelum tindakan pada nilai rata-rata 65,8 dengan prosentase tingkat kelulusan sebesar $=13,89 \%$ meningkat pada siklus I nilai rata-rata 73,8 dengan prosentase tingkat kelulusan sebesar $=72,22 \%$ dan meningkat pada siklus II nilai ratarata 82,0 dengan prosentase tingkat kelulusan sebesar $=100 \%$. Setelah menganalisis hasil tindakan setiap siklus dapat diketahui bahwa hasil data setiap siklus mengalami peningkatan, terutama pada siklus II, yang menjelaskan peningkatan yang signifikan pada prosentase sebesar $100 \%$ dari seluruh mahasiswa dengan jumlah 36 mahasiswa, sehingga penerapan model pembelajaran ini dalam katagori berhasil.

\section{E. DAFTAR PUSTAKA}


Gagne, R.M. dkk. (2005). Principles of intructional design. New York:Wadsworth Publishing Co.

Kemmis, S \& McTaggar, R. (1988). The action research planner (3rded). Melbourne: Deakin University Press.

Koper, R \& Tattersall. (Ed.) 2005). Learning design, a handbook on modeling andelivering networked education and training. Verlang Berling: Springer

Maclean, R. \& Wilson. D. (eds). (2009). International handbook of education forthe changing world of work. UNESCO. Paris: Springer.

Mulder, M., T. Weigel \& K. Collins (2006). The concept of competence conceptin the development of vocational education and training in selected EUmember states. A critical analysis. Journal of vocational education andtraining, 59,1, 65-85.

Mulyatiningsih, E. (2011). Riset terapan bidang pendidikan dan teknik.Yogyakarta: UNY Press.

Purwadinata, (2013). Psikologi Pendidikan dengan Pendidikan Baru. Bandung; PT Remaja Rosdakarya

Rusmono. (2012). Strategi Pembelajaran dengan Problem Based Learning Itu Perlu: Untuk Meningkatkan Profesionalitas Guru. Bogor: Ghalia Indonesia.

Suyitno, S. (2018). Penelitian Tindakan Kelas, Eksperimen dan R \& D. Alfabeta. Bandung.

Suyitno, S., Widianto, I., \& binti Masrul, S. (2018). Development of learning media for the course of two-stroke gasoline motors to improve students' learning outcomes. Jurnal Pendidikan Teknologi dan Kejuruan, 24(1), 83-90. https://journal.uny.ac.id/index.php/iptk/article/view/18008/10719

Suyitno, S., \& Pardjono, P. (2018). Integrated work-based learning (I-WBL) model development in light vehicle engineering competency of vocational high school. Jurnal Pendidikan $\quad$ Vokasi, 8(1), 1-11. https://journal.uny.ac.id/index.php/ipv/article/view/14360/10387

Rohmanato, R., \& Suyitno, S. (2018). PENGEMBANGAN MEDIA PEMBELAJARAN SISTEM KEMUDI TIPE RACK AND PINION UNTUK MENINGKATKAN PRESTASI BELAJAR SISWA PADA MATA PELAJARAN CHASSIS KELAS XI TKR SMKN 6 PURWOREJO TAHUN AJARAN 2016/2017. Auto Tech: Jurnal Pendidikan Teknik Otomotif Universitas Muhammadiyah Purworejo, 12(01). 
Sutrisno, Y., \& Suyitno, S. (2018). UPAYA MENINGKATKAN KEMANDIRIAN BELAJAR DAN PRESTASI BELAJAR MELALUI MODEL PEMBELAJARAN PROBINGPROMPTING PADA SISWA KELAS XI TKR B SMK NEGERI 4 PURWOREJO. Auto Tech: Jurnal Pendidikan Teknik Otomotif Universitas Muhammadiyah Purworejo, 12(02). http://ejournal.umpwr.ac.id/index.php/autotext/article/view/4882/4486

Anggoro, Y., \& Suyitno, S. (2019). PENGARUH PELAKSANAAN PRAKTIK INDUSTRI DAN MINAT WIRAUSAHA DENGAN KESIAPAN MENTAL KERJA SISWA KELAS XII JURUSAN TEKNIK SEPEDA MOTOR SMK MUHAMMADIYAH 1 TEMON. Auto Tech: Jurnal Pendidikan Teknik Otomotif Universitas Muhammadiyah Purworejo, 13(02). http://ejournal.umpwr.ac.id/index.php/autotext/article/view/5395/4933 